\title{
Using Instagram in Teaching Writing for University Freshmen
}

\author{
Rosyida Asma'ul Husna ${ }^{1}$, Mirjam Anugerahwati ${ }^{1}$, Furaidah ${ }^{1}$ \\ ${ }^{1}$ Pendidikan Bahasa Inggris-Univesitas Negeri Malang
}

\section{INFO ARTIKEL}

\section{Riwayat Artikel:}

Diterima: 30-07-2019

Disetujui: 24-09-2020

Kata kunci:
instagram;
reflective teaching;
process-genre based approach;
instagram;
pengajaran reflektif;
pendekatan berbasis genre proses

\section{Alamat Korespondensi:}

Rosyida Asma'ul Husna

Pendidikan Bahasa Inggris

Universitas Negeri Malang

Jalan Semarang 5 Malang

E-mail: rosssyida@gmail.com

\section{ABSTRAK}

Abstract: This study aimed at elaborating the use of Instagram in teaching writing for university freshmen. This current study contained a reflection from a lecturer who had used Instagram to improve students' writing skill through process-genre based approach. The data were taken from a reflective daily journal. Further, the journal specifically informed what worked well and what did not from the use of Instagram for writing skill improvement. The result showed that Instagram could significantly improve students' writing skill, especially to help them find that writing was part of social activities and create a good composition that had been perfectly finalized.

\begin{abstract}
Abstrak: Penelitian ini membahas tentang penggunaan Instagram dalam pengajaran writing skill (keterampilan menulis) pada mahasiswa tahun pertama. Penelitian tersebut berisi tentang sebuah refleksi dari seorang pengajar yang telah menggunakan Instagram sebagai media pendukung pembelajaran writing skill melalui pendekatan proses-genre. Data penelitian berasal dari jurnal harian yang sekaligus digunakan untuk mencatat serangkaian kegiatan yang dilalui pada proses pengajaran. Hasil dari penelitian ini menunjukkan bahwa penggunaan Instagram mampu meningkatkan keterampilan menulis mahasiswa sehingga mereka menyadari bahwa menulis merupakan bagian daripada kegiatan sosial serta, serta membantu mereka untuk bisa membuat sebuah karangan atau tulisan yang sempurna.
\end{abstract}

Now that English has been a vital necessity throughout the world for it is, commonly, set as the main requirement for scholarship or job application and had been lingua franca for decades ago, most of educational institutions attempt to give access to their students, either from English or non-English department to mastering English so as to help them fulfill the demand. In one of private universities in Malang, English has been set as the compulsory subject all the students have to attend for two solid semesters in the first year of their study, and it includes four basic skills, covering speaking, reading, writing, and listening. In addition, the materials provided are based on their focus of study.

Previously, the researcher has done a preliminary study at a private university in Malang through observation and interview. All non English Departments at this university offer English to their freshmen covering the four skills namely listening, speaking, reading, and writing. Thus, there is English for Communication Science, English for Accounting, English for Sociology, etc. Based on the researcher's observation on the teaching of writing at non English departments, there are many aspects that seem problematic to the lecturers in teaching writing. The problems are large classes which are common in writing classes. The condition is out of ideal because the numbers of the students are fifty to sixty students. The class is also mixed in ability in that some students are good at language some others are good at content. Their attitude toward language is also different. Some are positive and others negative. The next problem which is also the problem in teaching writing is motivation because the students see no value of their English course, and most students are not really serious in taking the course. They regard English as a non main subject so that English is considered less important.

In addition, Poedjiastutie \& Oliver (2017) argued that the quality of the student intake contribute to worsening the writing instructional session in the university. It is unlike the state universities that are fully funded by the government, as a private university, the university should commit a self-financing. Due to this fact, the university opens abundant quota of students; which is believed as another factor to make the English instruction problematic and affect the student's English proficiency level. Thus, they added that there is a need to create flexibility in teaching and to maximize learning for students. Teaching writing to non English department students is designed to provide students with specific skills to enable them to develop their profession, career, occupation, and specialization (Poedjiastutie \& Oliver, 2017). The undergraduate students later have to write sarjana's thesis with 
an abstract written in English. The students also have to be able to read research articles published in international journals, write articles and research report in English, and join international conferences. It is expected that the students could apply the knowledge and skills to write, present, and publish research articles in English. Moreover, the writing ability can be used in international forums and the students can use the skill to apply for scholarships abroad. Therefore, developing students' writing skill is undeniable.

Based on the observation and the importance of developing students' writing, it is crucial to have a reflection in action of teaching writing. The reflection portrayed in an actual action might be of necessity for the sake of teachers' identity and profesionalism (Kuswandono, 2014). It is hoped that implementing a new strategy will overcome the students' problem in writing. In present study, Instagram is set to be the instructional media that is believed effective to help the students generate a good writing as almost all the students in the class must have Instagram account. A supporting idea has come from Lie in 2015 who had had a try to apply using technology as a part of his teaching which was totally helpful to him. In addition, with the help of today's advanced technology, he was allowed to run a student-based model of instruction and lessen the dominance of teacher (Lie, 2015).

\section{METHOD}

A descriptive qualitative research design was employed in this study. The objective of this research was to describe the use of Instagram in teaching writing for university freshmen. To support the administration of the research, in addition, reflective teaching method was occupied. As concluded by (Lubis, 2018) reflective teaching would everlastingly foster professional autonomy of the $21^{\text {st }}$ century pre- and in-service EFL teachers. Thus, it is suggested that a highly-balanced reflective activities be raised and advanced as an optional assessing form in the teaching as it involves personal and social aspects (Astika, 2014).

The study was conducted in one of the advanced private universities in Malang, by involving as many as 14 freshmen from Communication Science Department, Faculty of Political and Social Sciences. The researcher appointed those students for teaching writing since it had been stipulated by Language Center, and the researcher could not determine the class by her own. The students are those who were taking a writing class within 14 meetings in total including mid-term and final tests. Each meeting, excluding the tests, was running for 100 minutes per week. The researcher herself was the lecturer of the class. As university freshmen, their ability in writing English composition is needed to be upgraded due to the lack of instruction in writing in their previous school.

In collecting the data, the researcher used three instruments, they are (1) reflective daily journals, (2) questionnaire, and (3) writing test. Reflective daily journals, as the primary instrument in this research, were useful for knowing the detailed information during the implementation in every stage of process-genre based approach including the students' participation. In addition, it was also used to define what worked and what did not after each lesson. The next instrument, questionnaire of students' reflection on the use of Instagram for writing, was aimed to get the students' opinion toward the use of Instagram. Students' opinions and perceptions can add a different and valuable perspective. It was adapted from (Muniroh, 2012). The questionnaire was given in the end of the meeting. The questionnaire was in the form of four open-ended questions. Writing test, as the last instrument, was given in the third meeting that was the meeting after the researcher finished implementing the instructional strategy. The students were assigned to write a descriptive text of a person. This writing test functioned to find the fact about students' improvement in writing descriptive text after the implementation of Instagram through process-genre based approach in teaching writing. How the use of Instagram in teaching writing for university freshmen is explained in more details in table 1.

Table 1. The Description of How Instagram are Used in Writing Descriptive Texts

\begin{tabular}{lll}
\hline \multicolumn{1}{c}{ Writing Stages } & \multicolumn{1}{c}{ Activities (Student-Centered) } \\
\hline $\begin{array}{l}\text { Building Knowledge of } \\
\text { Field (BKOF) }\end{array}$ & - & $\begin{array}{l}\text { See a picture of Isyana sarasvati through power point slide } \\
\text { Have question and answer session to recall background knowledge } \\
\text { related to descriptive text and its social function }\end{array}$ \\
\hline $\begin{array}{l}\text { Modelling of the Text } \\
\text { (MOT) }\end{array}$ & $\begin{array}{l}\text { Receive a model text entitled "Isyana" and read it silently (see appendix } \\
\text { (20 minutes) }\end{array}$ \\
& $\begin{array}{l}\text { Comprehend the text through question and answer session, then learn the } \\
\text { features of the text (generic structure), the language used (grammatical } \\
\text { structure and vocabulary) }\end{array}$ \\
& $\begin{array}{l}\text { See Isyana's Instagram Account containing profile picture and profile } \\
\text { information (bio) through LCD } \\
\text { Get the handout containing the printed Isyana's profile information and } \\
\text { profile picture } \\
\text { Get the descriptive scaffold then write the information from the profile } \\
\text { picture and profile information (bio) to the descriptive scaffold }\end{array}$ \\
&
\end{tabular}


Table 1. The Description of How Instagram are Used in Writing Descriptive Texts (continue table)

\begin{tabular}{|c|c|c|}
\hline $\begin{array}{l}\text { Joint Construction of } \\
\text { Text (JCOT) } \\
\text { The collaboration is } \\
\text { done in pairs }\end{array}$ & $\begin{array}{l}\text { Prewriting } \\
\text { - } \quad \text { See the profile picture and profile information (bio) of their classmate } \\
\text { Write the information from the profile picture and profile information } \\
\text { (bio) in the descriptive scaffold } \\
\text { Drafting } \\
\text { - Write a descriptive text based on the information in the descriptive } \\
\text { scaffold } \\
\text { Revising } \\
\text { - Revise the draft based on the feedback given by another pair. } \\
\text { Proofreading activity is done before based on the proofreading } \\
\text { guidance (see appendix) } \\
\text { Editing } \\
\text { Edit the draft based on the feedback given by another pair } \\
\text { Publishing } \\
\text { Post the final writing to Instagram account and give comments to } \\
\text { others' writing }\end{array}$ & $\begin{array}{l}\text { Publishing: } \\
\text { The day after } \\
\text { meeting } 2 \text { (the } \\
\text { students are given } 3 \\
\text { days for publishing } \\
\text { activity) }\end{array}$ \\
\hline
\end{tabular}

\section{RESULTS}

This chapter explains the use of Instagram as a medium for teaching writing to university freshmen in accordance with issues in the research, comprising: the reflective daily journals of the implementation of process-genre based approach, students' reflection on the use of Instagram for writing activity, and the assessment from the English instructors by using the scoring rubric.

\section{Reflective Daily Journals of the Implementation of Process-Genre Based Approach}

Reflective Daily Journals defined what worked and what did not after every stage of teaching writing using Instagram through process-genre based approach. The implementation of process-genre based approach was able to make the students write more confidently because they experienced the process of writing starting from prewriting, drafting, proofreading, revising, editing, and publishing both cooperatively and independently.

\section{Reflective Daily Journals of Building Knowledge of Field (BKOF) in Meeting 1}

Only four students were shown well understanding about the descriptive text and its social function; while the rest of whom remained silent and seemed to forget. In other words, only $28 \%$ of the whole 14 students (less than 50\%) were deemed potential to be successful to accomplish the material.

Using a power point slide and LCD could generate a conducive class. In addition to being more paperless, it was allowed to attract student's attention to the LCD display. With a gigantic display, students were supposed to get clearer sight and details; thus it eased them to create detailed description about the displayed picture.

Nonetheless, the LCD somehow technically went wrong despite its getting back normal afterwards. This sort of incident was anticipatable by means of students' smart-phones whenever they would like to access the handout used in the form of softfile. Handout distribution to students was deemed effective to make them faster to follow the materials being taught.

\section{Reflective Daily Journals of Modeling of Text (MOT) in Meeting 1}

After Q-\&-A session, the students were guided to define what descriptive text is actually about and identify elements that built the text. In this session, the students were to have a closer look at the PowerPoint slide that had been created by the teacher. The PowerPoint was supposed to explain and give proper examples of describing people based on their physical appearances, such as giving examples of types of hair, shapes of face, and degree of height or weight. In addition, the PowerPoint slide also comprised general information about generic structure of descriptive text, including: identification, description, and conclusion.

In this writing stage, model text was a fundamental foundation for students to create a good descriptive text. Therefore, the students were given a printed descriptive text telling about the same public figure Isyana, complete with several comprehension questions. Moreover, the students were given chance and time to comprehend the text and answer the given questions.

After the time was over, the students, along with the lecturer, started to discuss elements of the descriptive text by identifying the generic structures and answering the questions in descriptive scaffold. In addition, the students were also allowed to ask question related to diction, grammar use, or other aspects that might support the construction of the descriptive text.

In this meeting, in addition to strengthening the comprehension on the descriptive text, the students were also invited to probe the potential of Instagram in helping them make a descriptive text. Further, the examples were provided by the lecturer which had been collected from several Instagram accounts that depicted descriptive text writing. The example, then, were shown in a PowerPoint slide by means of laptop and LCD as they were supposed to give the students authentic examples of how to write descriptive text in their own Instagram accounts, later on. 
As a result, referring to the first activity on the meeting, as many as 11 out of 14 students (signifying $79 \%$ ) had been able to identify the generic structure of descriptive text and had been good in understanding its function. Meanwhile, in the second activity, after being given a good model of descriptive text in some Instagram accounts, the students had shown a significant upgrade in terms of writing descriptive text. Some of the students seemed recalling their prior knowledge about descriptive text. Besides, they looked quite enthusiastic as all of the illustrations shown were eye-catching and interesting.

At the end of the meeting, the students were divided for pair-work. For the pair-work, all of the pairs were to choose one picture of their classmates in their Instagram accounts. In addition, the students were to complete their personal information in the bio of their Instagram accounts. Further, the picture had to be screenshot and printed in A4 paper. To give the clearest view, the picture was supposed to be colored, instead of black-and-white.

The use of power point and meaningful drilling had shown an accurate outcome for a small class, with 14 students in total. The time would be in control, and each of them would receive equal portion of drilling. However, when filling the descriptive scaffold that had been distributed to the students, most of whom kept questioning something regarding how specific words, in Bahasa Indonesia, were produced in English, such as "What is 'mancung' in English, Miss?", What should we say to refer to "rambut botak", and so forth.

Online dictionary, therefore, was very possible to use as alternative solution to drive students more independent in enriching their vocabularies. By doing so, never would they make or express such questions in event of having no idea about what to say or write to describe someone's or something's look. In addition, descriptive scaffold also contributed to assisting students to write through a series of process from a phrase to a sentence. Establishing students with rich of vocabularies took time, but it did not with descriptive scaffold. Their ideas in writing continued to improve and never got stopped or stuck in two or three sentences. At last, the ultimate goal of using descriptive scaffold was that students were able to attain the set standard of writing descriptive text and to make it of contentment.

\section{Reflective Daily Journals of Joint Construction of Text (JCOT) in Meeting 2}

In meeting 2, the instruction was focused on creating a composition of descriptive text in pair based on the chosen picture by their own. The ultimate goal of this meeting was that all of the students posted their final product of descriptive text in pair through several stages, including pre-writing, drafting, revising, editing, and publishing.

In pre-writing, the students in pair wrote as many words or phrases as possible that were best describing the chosen picture of their classmates, specifically in respect of physical appearances and personal identities, by using descriptive scaffold given by the instructor. In this phase, the students were supposed to collect and identify as many as vocabularies to be used for their descriptive text. In pair, the students discussed the proper vocabulary for describing people appearances. Several students opened their notes from previous meeting to help them fulfilling the descriptive scaffold. In other words, they were about to build the most fundamental capital before they started to write.

The existence of profile picture and personal information (also known as 'bio' feature) of their classmates helped the students completed the descriptive scaffold. However, some chose and set low-quality picture for their Instagram profile. As a consequence, those who visited the accounts with low-quality photographs in personal information would be a bit hard to identify physical appearances and took time, especially in descriptive scaffold procedures. Additionally, what was written in personal information was also somehow not specific in details. As an alternative, they were allowed to seek and select one high-quality photograph besides attaching personal information in their accounts.

Moreover, in drafting stage, the students started to write their first draft of descriptive paragraph containing identification, description, and conclusion as learned in the previous meeting. Further, all of the drafts were used as the main object for revising stage. In the stage, all of the pairs swapped their drafts; therefore, they proofread the draft each other. This stage was supposed to activate the students to raise their awareness in identifying errors or mistakes by referring to proofreading guidance prepared by the instructor. After getting feedback, the students edited the drafts and submitted the final product to the instructor for better result in editing stage. At the end, in publishing stage, all of the students were to publish the final product that had been checked by the instructor in their own Instagram accounts.

Requesting students to publish their writing products, specifically in descriptive text, in social media platform had aroused a desire to put the same thing on other texts with different genres, such as report, procedure, and narrative ones. It was due to students' high enthusiasm in posting what they wrote to public, with a hash-tag '\#writingrosy', which resulted in great temptation. Thus, at the end, students could perform excellently during writing activities as part of social activity.

\section{Reflective Daily Journals of Independent Construction of Text (ICOT) in Meeting 3}

ICOT was conducted in meeting 3 , in which the students were asked to work individually for descriptive writing project by means of Instagram. In this stage the instructor had prepared a worksheet which contained a picture of a person. All the worksheet was made homogenous; thus, all of the students were to describe the same figure. After they were done with the writing description, they needed to submit the works to the instructor for feedback. At last, when the feedback had been internalized, they were to publish the writing to their own Instagram accounts individually. Afterwards, they needed to make reflection based on the result that they had received after posting their writing, whether it was related to how many likes they gained, how many people commented, how they felt when there was someone commenting not really good about their writing, and so forth. 
After checking each student's post on Instagram, many positively responded to the activity, including the workmate of the lecturer. They found that there were a few of errors found in students' writing. This was due to proofreading the students had taken first before publishing the writing. Thus, the posted writing constituted a draft which had met some expected requirements which were good, detailed, well-organized, equipped with very few of grammatical inaccuracy, and composed by effective sentence structures. Apart from minor misspelling occurrences, some were only found in the published writings. Nonetheless, its draft, in fact, had been perfectly finalized.

\section{The Students' Reflection on the Use of Instagram for Writing}

The data were taken from questionnaire in the form of four open-ended questions. Furthermore, the data presented in this sub-chapter were closely related to students' reflection upon Instagram as a means of writing activity. In details, the subchapters were divided and elaborated into four main points as follow:

\section{The most important thing that they have learned from the use of Instagram for Writing}

Based on the first reflection, it was reported all of the students (14 students) confessed that Instagram was very meaningful to their writing experience as it provided them with lots of joy. They were shown to have a positive action for writing whenever they were asked to access their Instagram account in behalf of their writing process. They would rather be writing using Instagram instead of paper for they think that today's era people must shift to a paperless trend.

Further, four students thought that writing through Instagram would allow them to keep connected to their close relatives; so that they would not think of that the writing activity was conducted for the sake of getting the best score. Rather, they would significantly think that it was the best means to communicate and express their feelings or notions through the caption that went along the posted picture.

\section{Something they already knew, but it was reinforced from the use of Instagram}

Most of the students (10 students) that were pointed out as the participants had been accustomed to descriptive text and writing it during in their high school levels. However, their competency in writing the descriptive text was said novice, still, due to lack of exposure to activate them writing the genre. The existence of Instagram in past recent years means so much to them. It has been their favorite platform to post their pictures with the captions (somehow they also enjoyed to see others' pictures and read the captions).

In addition, their motivation to write in Instagram was shown boosted up as their intention is not really for writing, but also for letting other people know about their existence. As the consequence, they felt demanded to reinforce what they had already learned, especially issue of grammar, in order to make sure the accuracy of their writing. Almost all of the students (10 students) stated that it was very shameful if their writing was not really accurate. As the consequence, it triggered their desire to have an in-depth learning about the grammar and sophisticated vocabularies for the caption, such as by accessing free English learning source, using dictionary by their own, and so forth.

\section{What worked well from the use of Instagram}

Instagram had been officially released and operated in 2010, and now it has been on the top of list of social media used by people, especially teenagers. In this study, Instagram was used as the main media to facilitate students advance their descriptive writing skill based on genre-based approach. In the conduct of the research, most of students had confessed that Instagram was quite interesting for learning due to supporting features created.

Firstly, in Instagram, they were allowed to change their profile photos as they wanted to. They said that it was a means of showing and getting closer to people. Secondly, the feature personal information allowed them to jot down their identity to people, including information of interests, disinterests, educational background, and so forth. Further, posting feature might be the most favorite among all features provided. The students were allowed to post their photo complete with a caption or description about it. This was very effective to invite them to write as long as possible to explain the essence of their photos.

The more photos they posted in Instagram, the more accustomed they would write many things in the Instagram; which was supposed to attract people to give their likes and comments on them ( 5 students). Moreover, when they notified that there were things to revise in their writings, they were still allowed to edit the descriptions by means of editing feature (10 students). The feature was very positive as it gave them chance to, somehow, make a reflection about what and how to correct. At last, there was a repost feature that allowed the students to directly adopt a photo along with its description that they thought it was good to share to other people ( 3 students). In addition, in the feature, the students were also allowed to edit and add some notes if necessary.

\section{What did not work well from the use of Instagram}

Since there had been people around the world using Instagram as their daily need for existence, posting and writing something in Instagram are said a bit risky due to chance of mockery that leads to bullying action ( 3 students). Some of the students confessed that when they were writing the captions on the posted pictures, they felt that they need to think about it for a couple of time to avoid the risk of being badly commented or abused by other people who found mistakes within the writing. As 
the consequence, they were often anxious and less confident to write for public. Besides, some of them (4 students) also stated that using Instagram for learning was somehow making them unfocused on the learning itself as the chance for joyful ups-anddowns scrolling was so open; instead of learning, they tended to find another pleasant activity of enjoying many pictures posted in Instagram.

\section{The Assessment from the Lecturers}

Not only has the students' attitude improved after the implementation of the strategy, but also the students' writing performance. Table 3 presents the result of assessment done by the two raters. It shows that all students had very good score above 80 (from the scale $0-100$ ).

Table 3. Students' Scores for Their Final Composition

\begin{tabular}{cccc}
\hline Students & Rater 1 & Rater 2 & Students' Mean Scores \\
\hline 1 & 90 & 86 & 88 \\
2 & 90 & 84 & 87 \\
3 & 88 & 90 & 89 \\
4 & 80 & 90 & 85 \\
5 & 90 & 88 & 89 \\
6 & 85 & 83 & 84 \\
8 & 90 & 80 & 85 \\
9 & 90 & 82 & 86 \\
10 & 90 & 84 & 87 \\
11 & 89 & 95 & 92 \\
12 & 80 & 92 & 86 \\
13 & 80 & 86 & 83 \\
14 & 85 & 83 & 84 \\
\hline
\end{tabular}

To support this study, two raters were employed. The first was the researcher herself, and the second was one of writing lecturers. The latter, in addition, was also a translator and had been experienced to deal with various kinds of writing. Therefore, the researcher was sure to appoint him as another rater.

Referring to the result of the student's writing, it was shown that, averagely, there was no significant difference from all the scores that had been given to the descriptive writing made by the students. The scores ranged from 80 (the lowest) to 95 (the highest); which meant that Instagram had been very effective to uplift the student's writing proficiency, especially in descriptive text. As a consequence, the means of the student's score were quite high and satisfactorily excellent.

As explained in the method of the study, the assessment was based on five criteria, to name content, organization, grammar, vocabulary, and mechanism. In terms of content, the students were to write based on the stipulated picture that had been chosen by the lecturer. The source of writing was set homogenous since the researcher would like to know how their writing would vary. As a result, all of them could make their own descriptive text with insignificant coincidence. In addition, they could make the story understandable, have a good flow, and have complete idea.

The topics they had written had been attached by supportive details. One of the examples was: "There is a girl whose name is Calita. She has a long and wavy hair (GZ, 153)." From the exemplification, GZ had been able to give a good detail that portrayed how the girl named Calita looked like.

The next was organization. In general, students had been able to create a good composition of descriptive text by following the standard or generic structure. All of the descriptive texts the students had made had been completed by two maj or parts of descriptive text, which were identification and description. They had known very well and been well familiar with it. The following was the example to prove from (EN, 167):

"I have a sister, and her name is Calita. She is a student in State University of Malang. Now, she is taking his Bachelor's Degree in Department of Mathematics." (Identification)

"Calita is so beautiful. She has big brown eyes. Also, she has got long hair, pointed nose, and very cute smile. Calita's hobby is swimming, like me actually." (Description). In addition, each student had different style of showing the identification part. They had their own portrayal of how they would create the identification. Despite one picture for all, many thoughts were generated.

In accordance with grammatical criterion, students had also well understood what tense to use for their descriptive texts. Most of them had made use of present tense in spite of insignificant error, such as "She likes reading novel before sleep (EN, 167). Referring to the tense used, it had been grammatically correct, but when looking at the word "sleep", the writer should make it "sleeping" instead of "sleep" due to the existence of preposition "before" preceded "sleep". This was not really urgent since the tense used had been based on the rule in common. That kind of occurrence was supposed to get 3 out of 4 in the rubric score for grammar matter. 
Along with the process of structuring their writing, they were going to find out the proper vocabulary that best suited the topic or target object. One to exemplify was in the following excerpt:

$$
\text { "Now, she is wearing floral clothes (AF, (176)" }
$$

The word "floral" was chosen to describe the outfit's motive that was being worn by the object to be described. Instead of saying "colorful", she preferred the term "floral" which showed that there was a process of deciding word to be used, especially to make their writing sound interesting. Almost all of the students had already known how to combine various words into a readable composition apart from the fact that there had been also some misuses of vocabulary, such as in the following excerpt:

"She is different than other sister (NA, 177)"

Instead of using "from" the writer preferred the word "than"; in which the word "different" should collocate with the word "from". This sort of misuse got bandwidth 3 out of 4 .

In mechanism point, the students were required to be able to write correctly in terms of spelling, punctuation, and capitalization. Based on the data, many students had been shown able to put capitalization and write based on the spelling correctly, but punctuation. Most of students were still problematic in using punctuation in their writing. The following examples were to show:

"Her mother name is Siti (NA, 177)"
"She has good personality, because she always ... (DP, 172)"

In the excerpt 1, there should be an apostrophe (') at the end of the word "mother" since it expressed possessive adjective pronoun. Thus, the writing should be "Her mother's name". Moreover, in the excerpt 2, comma should be deleted, for dependent clause did not need any comma unless it preceded the independent one. This might be serious concern because it seemed very simple but affected significantly.

All in all, the use of Instagram for teaching writing was just focused to make the students able and confident to write descriptive text in quite long paragraphs, and thus, the content valued the highest among the five, consecutively followed by the organization, grammar, and mechanism. It was due to their main discipline which was non-English department.

\section{DISCUSSIONS}

As stated as one of the findings of the study, the students who attended Instagram-assisted writing class had been shown more joyful and quite confident to write and share it to their close friends in spite of its social scope. This finding was in line with the finding proposed by (Afrilyasanti, 2012) stating that students were allowed to make use of English independently for networking communication for they did not need to feel afraid of making mistake or being scored by their teachers. This is very reasonable because when teachers administer a test or assignment with the purpose of taking score on them, the students might feel burdened and more tensed. They would consider it as a demand instead of self-improvement step.

In addition, the confidence of theirs led them to actively write something in their Instagram account which was also aimed to get connected to their close relatives, such as for sharing knowledge, jokes, or anything to discuss with through the captions they had composed. In other words, by Instagram, the students were facilitated to get closer to their social environment, in this case in behalf of sharing pieces of writing, manifesting their nature as a social creature. Not merely focused on the score they would get, the students were also exposed on how to socialize and get meaningful values with Instagram as a platform of communication.

Moving to another point, it had been stated in the study that using writing for teaching writing had brought significant impact to the students. They had found themselves allowed to let other people know about their existence not only in the real life, but also beyond it. This finding was in the same logic with the idea proposed by (Agustina, 2012) who claimed that student's participation in an authentic or natural setting of communication was allowed to sharpen their confidence representing a crucial factor for successful language acquisition. Referring to the case, the use of technology involved at the lesson plans could help the teachers transfer their creativity into reality, bring more real authenticity to the activities, and provide materials that vary on the topics discussed (Vu \& Febrianti, 2018). In other words, the more students get accustomed to writing via Instagram, the greater chance of the language acquisition would be. They are not likely to feel worried when they had been used to writing regularly despite possible errors in their writing.

In addition, this study had revealed that students had seen Instagram as a platform which was allowed to attract them to learn to write as long as possible in a form of a caption when posting their pictures. This was like the research conducted by (Irmawati, 2012) of which result showed that the use of Instagram was able to help students result in meaningful and set it organized into a descriptive writing. Additionally, they would get the chance to write the descriptive text from either cooperative or independent work during the process of writing. Moreover. the finding found that both cooperative and independent works during writing process could make the students show a positive response and betterment; which had resulted in powerful essence of learning and sharing (Rodliyah, 2016). 
Moreover, this study showed that actually students were shameful if they made a mistake in their caption so as to motivate them to keep learning about grammar. In other words, they were quite keen to learn until they know how to make a very good composition which was grammatically correct. Also, (Pan, 2010) had found that teacher error feedback contribute to very insignificant impact to students' ability to write acurately

Furthermore, alluding to the researcher's own reflection, it was found that students were highly interested to current social media development and inclined to follow any sorts of renewal made. This was in line with the research conducted by (Sahdan, 2010) and (Nurliana, 2010) which used internet resources and social media in teaching English. During her teaching sessions, often had she found that most of students seemed ignorant to the teaching, but more interested at accessing their social media. By using social media, the students seemed to be more confident to find themselves able to write properly. As a consequence, the students had been more advanced, from writing manually to writing digitally with the help of technology.

In addition, reflective teaching had helped the researcher promote genre-based approach to the students as a part of writing process. This was similar to (Fakazli, 2017) who engaged various tools in reflective practice. Further, the result had revealed that genre-based approach was possible to be implemented by means of technological mobile in order to improve students' writing skill (Noriega, 2016). Consequently, the students were aware that writing was not that simple. There were some procedures to get through as, in genre-based approach, there were four procedures in total. Thus, the students were supposed to know and internalize each of the procedures for the sake of meaningful writing works, consisting of building knowledge of text (BKOF), modelling of text (MOT), joint construction of text (JCOT), and independent construction of text (ICOT).

\section{CONCLUSION}

Alluding to the result of the study, it was shown that Instagram had brought a significant impact to the students, especially to empower them to learn writing a descriptive text. With all the uniqueness and features set in it, Instagram had fruitfully boosted up the student's desire to learn more keenly. In addition to motivating the student's learning, using Instagram had also impacted their social life as they could write something for the sake of getting closer to other people and showing their existence.

Besides, the implementation of genre-based approach had also taught them that writing really took time, for it included some procedures, such as; pre-writing, drafting, editing, revising, and publishing. This series of process was very meaningful and really opened their mind to take into account what to write for public sharing. When they made a mistake, they actually still had a plenty of time to make reflection upon their writing during the process.

Moreover, the researcher, also as the main administrator of the teaching, had played very important role in making use of Instagram combined with the implementation of genre-based approach. Thus, she had found that this sort of reflective research was really essential to inform other educational practitioners about the significance of Instagram in assisting students in writing class.

Despite the excellence of genre-based approach to help students write descriptive text, the use of social media is also of significance. It is because the existence of social media has been in students' blood. Most of them must have social media as a means of expressing their ideas. Therefore, instead of letting them have fun with it, why not the lecturers make use of it to help them able to write well.

As one of the productive skills one should master when learning English, writing consists of so many things to begin with. Therefore, it is of necessity to always make a significant renewal on the way or method to teach it along with the development of technology.

Instagram had just been officially released in 2010, but in its 10-year existing, rarely do people make use of it as a means to share knowledge. Otherwise, it is always attached with some interesting supportive features which are also able to be used for the need of learning, especially language. Thus, considering the great benefit of Instagram nowadays for writing empowerment, the researcher suggests that the upcoming researchers be sensitive to what is being up-to-dated on its feature renewal so that they can make use of it to create a similar model of learning, but with significant improvement.

In addition, since there are also some features like, "live video, Ig TV, and video posting, it is very possible, too, to make it a platform to enhance student's speaking skill. The researcher is pretty sure that it will work well as Instagram today has been positioned the most used social media compared to other social media platforms, with all improvements currently existing. With significant improvisation on its features, later, teaching all English skills might be on ease.

\section{REFERENCES}

Afrilyasanti, R. (2012). The Use of English for Classroom Interaction and Networking Communication in EFL Learners' Context. In Englishes for Communication and Interaction in the Classroom and Beyond (pp. 439-449). Malang: State University of Malang Press.

Agustina, L. (2012). Using Authentic/Natural Atmosphere. In Englishes for Communication and Interaction in the Classroom and Beyond (pp. 451-462). Malang: State University of Malang Press.

Astika, G. (2014). Reflective Teaching as Alternative Assessment in Teacher Education: A Case Study of Pre-Service Teachers. 25(1), 16-32. 
Fakazli, Ö. (2017). Reflection on Reflection: EFL University Instructors Perceptions on Reflective Practices. Hacettepe University Journal of Education, 19-19. https://doi.org/10.16986/HUJE.2017025118

Irmawati, D. K. (2012). Using Facebook through Process-Genre Based Approach as an Interactive Strategy in Writing Descriptive Texts. In In Englishes for Communication and Interaction in the Classroom and Beyond (pp. 403-420). Malang: State University of Malang Press.

Kuswandono, P. (2014). Voices of Pre-Service English Teachers: Reflecting Motivations During Practicum Learning. 25(2), $185-202$.

Lie, A. (2015). Social Media in A Content Course for The Digital Natives. 24(1), 48-62.

Lubis, A. H. (2018). Reflective Teaching Toward EFL Teachers' Professional Autonomy: Revisiting Its Development in Indonesia. International Journal of Education, 11(1), 35. https://doi.org/10.17509/ije.v11i1.9400

Muniroh, S. (2012). Using Conference to Develop Students' Writing skill. In Englishes for Communication and Interaction in the Classroom and Beyond (pp. 412-438). Malang: State University of Malang Press.

Noriega, H. S. R. (2016). Mobile Learning to Improve Writing in ESL Teaching. 27(2), 48-62.

Nurliana, Y. (2010). Using Facebook to Improve Students' Achievement in Writing escriptive Text at SMAN 1 Karangan Trenggalek. State University of Malang, Malang.

Pan, Y. (2010). The Effect of Teacher Error Feedback on The Accuracy of Efl Student Writing. 21(1), 21.

Poedjiastutie, D., \& Oliver, R. (2017). English Learning Needs of ESP Learners: Exploring Stakeholder Perceptions at an Indonesian University. 28(1), 21.

Rodliyah, R. S. (2016). Using A Facebook Closed Group to Improve EFL Students' Writing. TEFLIN Journal - A Publication on the Teaching and Learning of English, 27(1), 82. https://doi.org/10.15639/teflinjournal.v27i1/82-100

Sahdan. (2010). Using Facebook to Teach Students to Write Descriptive Texts. In In Teaching English by Using Internet Resources (pp. 183-187). Malang: State University of Malang Press.

Vu, T., \& Febrianti, Y. (2018). Teachers' Reflections on The Visual Resources in English Textbooks for Vietnamese Lower Secondary Schools. 29(2), 266-292. 